\title{
Good Governance of Food Security in Nunavut
}

\author{
Karolina Stecyk ${ }^{1}$ \\ Athabasca University, Alberta, Canada \\ Correspondence: Karolina Stecyk, Athabasca University, Alberta, Canada. \\ E-mail: karolina.stecyk@mail.utoronto.ca \\ Received: February 22, 2018 Accepted: March 20, 2018 Online Published: May 4, 2018 \\ doi:10.5539/jfr.v7n4p7 \\ URL: https://doi.org/10.5539/jfr.v7n4p7
}

\begin{abstract}
Food insecurity is not a new issue in Nunavut, Canada, but it is one that is not yet resolved. In Nunavut, the Government of Canada primarily through Indigenous and Northern Affairs Canada manages food security. In 2011, to aid the issue of food insecurity, the Government of Canada created the program called Nutrition North Canada (NNC). This paper will identify the values and mandate of Indigenous and Northern Affairs Canada and Government of Nunavut and state the current status, challenges, and health impact of food security in Nunavut. Lastly, it will determine if the Government of Canada is following the principles of good governance with the Nutrition North program, and suggest improving competencies like innovativeness, strategic thinking and building collaborative relationships by expanding agriculture and aquaculture in Nunavut to assist in tackling food insecurity.
\end{abstract}

Keywords: food security, policy, good governance, Nutrition North Canada

\section{Introduction}

Food insecurity is not a new issue in Nunavut, Canada, but it is one that is not yet resolved. Food security is defined as people having physical, social, and economic access to sufficient, safe and nutritious food, permanently, to live healthy and active lives (McDonald, 2013, p. 1979). The United Nations Development Program (UNDP) recognizes that food security is one of the seven main threats to human security (McDonald, 2013, p. 2000). The UNDP states that people should be entitled to food, grow it for themselves, buy food, and take advantage of a food distribution system (McDonald, 2013, p. 2000). In Nunavut, these options are not available to its utmost capability. A key organization ensuring food security is the government. Food security is dependent on good governance by the government because it has the power to create programs and policies that can make availability and accessibility possible. There are 5 key principles for good governance: legitimacy and voice, direction, performance, accountability, and fairness (Graham et al., 2015, p. 3). In addition to following the principles of good governance, governments need to have appropriate values and competencies. Values are "a principle, standard, or quality considered to be worthwhile or desirable" or "a belief... that predisposes one to act in a certain way" (Kirschenbaum, 2013, p. 177). Competencies are "skills, knowledge, experience, attributes, and behaviours that an individual need to perform a job effectively" (Patria, 2011, p. 27). Values and competencies help shape and drive programs and initiatives to improve and eliminate food insecurity. In Nunavut, the Government of Canada primarily through Indigenous and Northern Affairs Canada manages food security. In 2011, to aid the issue of food insecurity, the Government of Canada created the program called Nutrition North Canada (NNC). This paper will identify the values and mandate of Indigenous and Northern Affairs Canada and Government of Nunavut and state the current status, challenges, and health impact of food security in Nunavut. Lastly, it will determine if the Government of Canada is following the principles of good governance with the Nutrition North program, and suggest improving competencies like innovativeness, strategic thinking and building collaborative relationships by expanding agriculture and aquaculture in Nunavut to assist in tackling food insecurity.

\section{Values and Mandate}

Values provide a foundation for what an organization believes in, and a mandate is an official order that the organization follows. The values of the Department of Indigenous and Northern Affairs Canada (INAC) in the Government of Canada and the values of the Government of Nunavut should align with initiatives to ensure food security. INAC states that it "values the cultures, traditions, and beliefs of those with whom we interact. Through 
honesty, transparency, and commitment we build an environment of trust, where common goals can be realized. Working collaboratively, we strive to ensure that the people we serve - First Nations, Inuit, Métis and Northern Communities - are healthy, safe, self-sufficient and prosperous" (Government of Canada - Indigenous and Northern Affairs Canada[INAC], 2017a, p.1). The values show that INAC included transparency, which is a principle of good governance, and INAC wants Indigenous people to be healthy, safe, and self-sufficient which are factors of food security. INAC's mandate is "to improve social well-being and economic prosperity; develop healthier, more sustainable communities; and participate more fully in Canada's political, social and economic development - to the benefit of all Canadians" (Government of Canada - INAC, 2017a, p.1). The mandate shows that a priority is to develop healthy and sustainable Indigenous communities taking into considerations economic development. Aside from INAC, the Government of Nunavut is an important stakeholder in food security because it is responsible for the territory, and its values and mandate needs to be aligned with INAC's values to establish the common goal of food security. In Nunavut, Inuit societal values guide government. The principles are:

"Inuuqatigiitsiarniq, that means respecting others, relationships and caring for people, Tunnganarniq, that means fostering good spirits by being open, welcoming and inclusive, Pijitsirniq, that means serving and providing for family and/or community, Aajiiqatigiinniq, that means decision making through discussion and consensus, Pilimmaksarniq/Pijariuqsarniq, that means development of skills through observation, mentoring, practice, and effort, Piliriqatigiinniq/Ikajuqtigiinniq, that means working together for a common cause, Qanuqtuurniq, that means being innovative and resourceful, and Avatittinnik Kamatsiarniq, that means respect and care for the land, animals and the environment." (Government of Nunavut, 2017b).

The values suggest that Nunavut wants to develop into a flourishing territory. It mentions competencies of innovativeness and resourcefulness that can help enable food security. The Government of Nunavut does not have an independent mandate. Each ministry has its own mandate (Government of Nunavut, 2017a). There is no direct ministry working on food security. However, the closest ministry potentially associated with food security is the Ministry of Economic Development and Transportation. Its mandate is "working in partnership to support Nunavummiut in stimulating and strengthening the economy and to ensure the safe and effective movement of people, goods, and knowledge" (Government of Nunavut, 2017c). The mandate does not clearly relate to food security, but the economy has a relationship with food security. Food security serves as the basis to achieve sustained economic growth. According to the UN Food and Agriculture Organization, high rates of malnutrition can lead to a loss in the gross domestic product (GDP) of as much as 4\% to 5\% (Torero, 2014). According to The Lancet, a global health and nutrition scientific journal, a $10 \%$ increase in economic growth reduces chronic malnutrition by $6 \%$ (Torero, 2014). The Government of Nunavut should consider creating a mandate that supports food security. Overall, INAC is supportive of Indigenous and Northern Canada's issues. At the same time, the Government of Nunavut values positive, socially/culturally acceptable progressive changes but has not specified the importance of food security.

\section{Current Status of Food Insecurity}

Canada is not typically associated with food insecurity. In most provinces, around the major metropolitan areas, food availability, and accessibility are prevalent. When looking at food insecurity in Canada, Health Canada collects health statistics through the Household Food Security Survey Module (HFSSM). In 2009-2010, in Nunavut, $28.8 \%$ of all households were food insecure, $14.7 \%$ were moderately food insecure, and $14.1 \%$ were severely food insecure (Health Canada, 2012). In comparison, Canadian provinces and territories food insecurity varies from $6.1 \%$ to $11 \%$ (Health Canada, 2012). According to the University of Toronto (2017), $45.2 \%$ of households in Nunavut are food insecure (3,200 households). The statistics show that Nunavut is significantly more food insecure compared to the other provinces and territories. Regarding age of people who suffer from food insecurity, a not-for-profit organization called "Feeding Nunavut" states that $60 \%$ of Nunavut's children live in food insecure household (62\% according to the University of Toronto (University of Toronto, 2017)), 70\% of Inuit preschool children live in food insecure homes, and $76 \%$ of severely food insecure children regularly skip meals (Feeding Nunavut, 2014). Many parents do not send their children to school because their children have not eaten. In fact, many parents do not eat themselves in order to feed their children (Bambury, 2015). Therefore, all people, regardless of age are eating poorly in Nunavut. Since other provinces and territories are mostly food secure, the government of Canada and the Government of Nunavut ("the governments") need to have a strategy to address the food insecurity issue amongst the demographic in Nunavut.

\section{The Challenges}

In a western country, due to its advanced technology, modernity, and wealth, food insecurity should be easy to 
solve. However, in Nunavut, food security has many challenges. The government faces challenges of location, ethnic make-up, and climate when creating programs and policies for tackling food insecurity. Nunavut is different from the rest of territories and provinces because it has limited roads, and there are many islands that are not connected to the rest of Canada. Therefore, transportation is difficult. The only way to transport food to the islands is by plane or ship. If there are bad weather conditions, transportation may be cancelled causing people not to access food or other supplies (Stevenson, 2017). Also, Nunavut has a small but growing population. According to the Nunavut Bureau of Statistics, the population of Nunavut in 2014 was 36,687 (Nunavut Bureau of Statistics, 2015), and as of July 1, 2017, the population is 37,996 (Government of Nunavut, 2017d). As the population grows, more food will be needed to sustain the population. Creating and maintaining strong food programs and initiatives help establish food sustainability and security. Regarding the ethnic make-up of the population, almost $85 \%$ of the population is Inuit (Nunavut Bureau of Statistics, 2016). The importance of this is that the Inuit compared to other Indigenous groups and ethnic groups in Canada have a specific culture and lifestyle that need to be considered when discussing food cultivation and consumption. Also, they are a population that has lived in the Arctic for over 4,000 years (Rea, 2017). Since they have been living there for so long and were able to survive, the Inuit can provide valuable information regarding food sustainability and security. In addition, their culture and lifestyle affect what food they consume. Traditionally, Inuit relied on "country food" ("country food") (hunting caribou, seal, fish, wild berries etc.) (Newman, 2015a). Inuit were traditionally hunter-gatherers because they did not farm (as no arable land is available) (Dam \& Dam, 2008, p. 32). Therefore, any program or initiative created needs to consider the Inuit history because the Inuit may not have the skills to cultivate food and may only be accustomed to eating certain foods. Also, as the population increases "country food" may not cover the entire required nutrition that the Inuit and minority groups need. Overall, the governments need to consider the location and transportation options, habitants and population trends, and history to effectively address the issue of food insecurity.

Another challenge in Nunavut is the climate and environment and its impact on agriculture. The climate and impact on agriculture play an important role in food security because it ultimately determines the yields of products and what and when food crops can be grown. In Nunavut, aside from the local sea and land animals, there is not much development of agriculture. In other provinces and territories, agriculture is a well-developed industry. On the other hand, Nunavut has limited development due to the climate. The temperature varies depending on the community. The warmest community in Nunavut is Kugluktuk with temperatures that rise to $30^{\circ} \mathrm{C}$ in the summer and in winter it range from $-15^{\circ} \mathrm{C}$ to $-40^{\circ} \mathrm{C}$. In comparison, the coldest community is Grise Fiord, with summer temperatures rising above freezing to $5^{\circ} \mathrm{C}$ and winter temperatures dropping to $-50^{\circ} \mathrm{C}$ (Nunavut Tourism, 2017). Similarly, to temperature, sunlight varies depending on the community and solstice. Also, there is little rainfall, and ice melts very slowly (Nunavut Tourism, 2017). Iqaluit's (capital of Nunavut) average January temperature is $-26.7^{\circ} \mathrm{C}$, and in June and July the snow is gone and the sun is up for 18 to 20 hours a day (Nobel, 2013). The cold temperatures and variations across Nunavut make agriculture difficult to develop since most fruits and vegetables require warmer temperatures and rainfall. Therefore, accessibility and availability of food are more difficult. Altogether, the climate is not ideal for agriculture.

Aside from the natural environment, there are concerns about global warming that is causing ice and snow to melt. From 1840 to the middle of the 20th century, the Arctic reported the highest temperatures. The high temperatures cause the permafrost to melt, contributing to the carbon cycle (Moran, 2015, p 146). Climate change can disturb the current vegetation and migration patterns of animals. According to the World Food Programme, climate change can have an effect on food availability by affecting yields, quality, and quantity of crops as well as food access, ultimately increasing food prices. Also, it can influence on food utilization because people will consume fewer calories resulting in bad nutrition and cycles of disease (health impact) and hunger (dietary diversity and food security), and food stability, because there may be the climatic variability produced by more frequent and intense "fluctuations in food availability, access, and utilization" (World Food Programme, 2017). The climate change may result in extreme weather events like droughts, floods, and storms. These events can "destroy crops, critical infrastructure, and key community assets, therefore deteriorating livelihoods and exacerbating poverty," and there are long-term and gradual climate risks because "glacial melt will affect the quantity and reliability of water available and change patterns of flooding and drought" there may also be a rise of the sea-level that can affect the "livelihoods in coastal areas and river deltas" (World Food Programme, 2017). The climate disruption hinders the Nunavut from growing and obtaining food, including traditional hunting. On the other hand, the change could bring the possibility of other vegetation growing. The governments need to consider the climate and its challenges and opportunities for food security when creating programs and policies.

Presently, since country food does not yield enough to support the Inuit, and the climate is challenging for 
growing food, the only way to bring in food and other items is by ship or by plane. The challenge is that these two methods have a high cost. For example, the store "Giant Tiger" in Winnipeg, Manitoba states it costs $\$ 198,000$ a year to stock. In comparison, a grocery store in Arviat, Nunavut states their cost is $\$ 2.2$ million (Strapagiel, 2012). In turn, the little food that Nunavut has is extremely expensive (Newman, 2015a). Also, food in Nunavut costs twice as much as the Canadian average. According to the Nunavut Bureau of Statistics, most Canadians pay $\$ 5.03$ for a 2.5-kilogram bag of white flour while in Nunavut, it costs $\$ 13.60$ (Nobel, 2013; CBC News, 2015). Another example is a head of cabbage; it costs $\$ 28$ in Nunavut (Nobel, 2013). In Ontario, a cabbage costs between $\$ 1.25$ and $\$ 2.50$ (Canadian Organic Growers, 2016). On average, Nunavutans spend $\$ 500$ to $\$ 600$ per week on food and they are also supplementing their budget by hunting and fishing (Bambury, 2015). According to the Geographical Journal, a basket of food for a family of four in Igloolik cost $\$ 551$ while for a family in Montreal the cost was $\$ 238$ (Ford \& Beaumier, 2011). On average, people in Nunavut pay around $\$ 14,000$ a year per household on groceries (CBC News, 2014a). Lastly, it is important to note that the average weekly income is $\$ 1,275.38$ (Statistics Canada, 2017) $(\$ 66,319.76$ per year), but half of the Inuit make under $\$ 20,000$ (CBC News, 2014b). The data shows that a significant portion (21\% with the average income and ((-/+) $70 \%$ of the Inuit income) of the Nunavutans salary goes towards purchasing food. However, they are unable to purchase much food because of the high costs and non-availability. In 2016, 19.5\% of Inuit in Nunavut were unemployed (Strong, 2017) and according to the Nunavut Bureau of Statistics, 13.7\% of Nunavutans are unemployed (Government of Nunavut, 2017d). The Government of Canada and Government of Nunavut need to consider the costs involved with food. The low income and the high cost of food hinders food security. Overall, the type of food insecurity that Nunavut faces is chronic food insecurity. Chronic food insecurity is when there is a lack of food available yearly (Chung, 1997, p. 8). The chronic food insecurity is driven by poverty because people are unable to obtain food or produce food (Braun, 1992). The high costs of food and low employment and salaries result in poverty then causes chronic food insecurity. The Government of Canada and Government of Nunavut need to create policies and programs that will overcome the challenges of low salaries, high food transportation costs or high purchase costs.

\section{Health Impact}

There are many impacts that food insecurity can have on people. Primarily, in Nunavut, the lack of sufficient, safe, and nutritious food has a significant impact on the health of the Nunavutans, especially the Inuit. The Commission on Human Security determined that people who do not have food security suffer from malnutrition (McDonald, 2013, p. 2000). Malnutrition can cause significant health problems and even death. Historically, the Inuit sustained themselves successfully. However, now, the Inuit eat much differently compared to their ancestors. The change in diet occurred upon the arrival of the Europeans (Stern, 2010, p. 164). Presently, in Nunavut, the Inuit eat country (traditional food) and commercial foods. Since the Arctic ecosystem only contains a few plants grown in the summer, most of the Inuit diet used to be meat based like seal, walrus, and whale. The traditional diet provided all the vitamins and micronutrients because the meats were eaten raw, frozen or lightly cooked. The diets were low in sugars and saturated fats and high in protein. The Inuit have no history of diseases or vitamin deficiencies (Stern, 2010, p. 164). The Inuit could obtain all the required nutrients from the foods that they ate. For example, Vitamin A found in fruits and vegetables is available to the Inuit in the oils of cold-water fish and sea mammals that are also a good source of protein and omega-3 fats (Albala, 2011, p. 197). Vitamin C was derived from ascorbic acid from fresh meat. In recent years most of the vitamin $\mathrm{C}$ is derived from western food. Traditional food only accounts for $20 \%$ of total vitamin C intake (Moran, 2015, p. 145-146). The hunting, gathering, preparation, and eating of country food are a key aspect of Inuit identity. The sharing of food reminds the Inuit of their cultural heritage and serves as a connector to their past. Hunting feeds families and sustains Inuit language and culture (Albala, 2011, p. 197). Therefore food and the practices of consumption are a social aspect. In addition, even though the Inuit currently fish, there are increased levels of cadmium, lead, and mercury in traditional meat and fish eaten (PCBs polychlorinated biphenyls) (Albala, 2011, p. 197). Therefore, traditional fish consumption needs to be done in moderation to ensure there are no negative impacts from the chemicals. Moreover, today, market foods are appealing due to taste and convenience. Country foods are now a much smaller portion of their diet and Inuit consume fewer species of animals (Stern, 2010, p. 164). Over half of the fat is currently imported; Inuit eat more carbohydrates from bread, cereals, rice, and sugar (Moran, 2015, p. 146). The shift from the traditional diet of meat and fish to commercial foods that are usually high in sugar and carbohydrates caused an increase in obesity, cardiovascular disease, acne, anemia, dental cavities, and type 2 diabetes (Moran, 2015, p. 146; Albala, 2011, p. 197). The transition from traditional eating to current western diets shows the negative health impact. If only the unhealthy foods are available, then that is what the Nunavutans will eat. On the other hand, as mentioned previously, both the healthy and unhealthy foods are unavailable for regular access. In 2016, Nunavut spent $\$ 533.8$ million on healthcare (Nunavut Bureau of 
Statistics, 2017). Ensuring that people in Nunavut are well fed will reduce the cost of healthcare. Without stable and long-lasting food security, there will be a continued negative effect on government fiscal costs. The connection between food and healthcare shows that the issues are interlaced and a solution for food security needs to be interdisciplinary.

\section{Nutrition North and Good Governance}

The problem of food security needs to be solved by a program that follows the principles of good governance because the principles can shape the program to comprehensively consider the needs of the people that the program is supposed to help and ensure that it is reliable and operating effectively. The first principle is legitimacy and voice that states that all genders have the right to voice their opinions in the decision-making process and there needs to be consensus orientation. It suggests that the government needs to mitigate different interests to reach the best interests of a group. The second principle is direction that requires a strategic vision where leaders and the public have a long-term perspective and are aware of what is needed for the development; this includes "an understanding of the historical, cultural and social complexities in which that perspective is grounded" (Graham et al., 2015, p. 3). The third is performance that requires responsiveness to serve all stakeholders and effectiveness and efficiency to make the best use of resources (Graham et al., 2015, p. 3). The fourth is accountability, it requires the decision-makers in government to be accountable to the public and be transparent showing that there is a free flow of information, that people can access, understand and monitor the progress. The fifth principle is fairness and it requires equity, meaning everyone has equal opportunities and the rule of law that requires "legal frameworks to be fair and enforced impartially, particularly the laws on human rights" (Graham et al., 2015, p. 3). The following section will determine if the Nutrition North Canada (NNC), led by the Government of Canada is successfully following the principles of good governance.

As mentioned above, one of the principles of good governance is direction. In 2011 the Canadian Government introduced the NNC program. This program replaced the food mail program that ran from the 1960s that subsidized Canada Post to ship freight to remote retailers. The government determined that food remained expensive and the program was abused because people used the subsidy to bring dishwashers and truck tires into the territory (Edwards, 2015). NNC's goal is to offset the high costs of food and bring healthy food to isolated Northern communities (Bambury, 2015). The goal shows that the government's direction is reducing food costs and providing accessibility to healthy food. The NNC subsidizes perishable nutritious food and commercially-produced country food for eligible communities (Government of Canada - INAC, 2017b). The nutritious foods are determined by the Revised Northern Food Basket (RNFB) that "measures the cost of a nutritious diet for a family of four for one week using 67 standard food items". NNC uses the RNFB to monitor the cost of healthy eating (Government of Canada - INAC, 2017b). The program works with stores across the North and food suppliers in southern Canada to help make perishable, nutritious food more affordable and more accessible to northern communities (Bambury, 2015; Government of Canada - INAC, 2017c). The subsidies are "passed on from the retailers and suppliers to the consumers and only registered retailers, suppliers, processors, and distributors can claim subsidies" (Government of Canada - INAC, 2017b). The direction of the program working with different food operators shows that the government is building collaborative relationships. In addition, the registration of retailers, suppliers, processors, and distributors shows that the government is being transparent and accountable because there are certain requirements that these groups need to meet to provide the service. Lastly, from 2011 the Government of Canada invested \$60 million in the program each year. The funding included community-based nutrition education through Health Canada (Bambury, 2015; Government of Canada - INAC, 2017c). The importance of the investment is that the government is devoted to spending the resources necessary to ensure that the program is successful. If the program was not well defined or developing, the government would not continue to provide funding.

Regarding the next principle of good governance, fairness, the program attempts to reach all communities and has a fair subsidy rate. The subsidy rate in each community is determined by four criteria: distance from the supply centre to isolated community, distance flown, the population, and minimum wage (Government of Canada - INAC, 2017c). There are two subsidy levels. The first level (level 1- high) is the most nutritious perishable food. The second level (level 2 - low) is for staple foods. There is a subsidy rate for country foods, but it varies depending on the "location of the country food processor/distributor and the eligible community". In 2016-2017, the subsidy budget was $\$ 80.6$ million and is distributes fairly and equitably among eligible communities. As a result, subsidy rates differ from one community to another (Government of Canada - INAC, 2017c). Therefore, the subsidies are handed out based on need, which shows that the program is being fair. However, not all the foods in the RNFB are eligible for a subsidy because "it is cheaper for retailers and customers to ship non-perishable food such as rice and dry pasta by winter roads, sealift, or barge" (Government 
of Canada - INAC, 2017b). The lack of eligibility of non-perishable food items is ineffective for improving food security because even though these foods are cheaper, the Nunavutans still have limited access. Moreover, these items are usually a staple for many meals. Also, another flaw is that the RNFB has limited fruits and vegetables. For example, the only fresh fruits available are apples, bananas, grapes, and oranges, and the only fresh vegetables are potatoes, carrots, onions, cabbage, and turnips (Government of Canada - INAC, 2017b). The limited fruits and vegetables are unfair because Canadians across Canada have accessibility to other fruits and vegetables like peaches, cherries, beets, and kale that have more nutritional values. The program should consider ways to make more food varieties available for the Nunavutans.

Regarding performance, the programs function is clearly defined. The most nutritious perishable food items such as milk, eggs, meat, cheese, vegetables, and fruit that can be fresh, frozen, refrigerated or have a shelf life of less than one year, only shipped by air get a higher subsidy level (Government of Canada - INAC, 2017b). Country foods like Arctic char, muskox, caribou, etc. are also subsidized. Their conditions are that it must be either "shipped by plane from a registered Country food processors/distributors and processed in a government regulated and/or approved-for-export commercial plants or shipped by plane from the South by a registered Northern retailer or Southern supplier and subsidized at the same level as other store-bought meat (level 1 subsidy) in the eligible food list" (Government of Canada - INAC, 2017b). The healthy food with the high subsidy level suggests that the government is following the direction it determined important. The inclusion of country foods into the subsidy program shows that the government considered the Inuit's culture and aligns with the previous principle, fairness. Regarding performance results, the government reports that between April 2011 and March 2015, the cost of a food basket for a family of four dropped by approximately 5\%. Also, between 2011 and 2016 the weight of eligible items shipped to northern isolated communities increased by approximately 25\%. Lastly, the government indicated that the nutrition education initiatives funded by Health Canada and the Public Health Agency of Canada have effectively increased knowledge of healthy eating and improved peoples' skills to choose and prepare nutritious foods (Government of Canada - INAC, 2017c). Also, the youth are provided more nutrition-related information through on-the-land camps, school-based activities and after-school programs and there is more partnering with local stores to promote health (Health Canada, 2012). Therefore, the NCC has successfully reduced some food prices on eligible items and people are more knowledgeable about nutritious eating.

On the other hand, the program's operation and performance have been criticized. On November 25, 2014, the auditor general Michael Ferguson, released an audit of the program (The Canadian Press, 2014). He stated that food remains inaccessible, the food is unaffordable, the appropriate data is not being gathered to measure success, and not all communities are receiving the food based on need (Government of Canada, Office of the Auditor General of Canada, 2014). Having clear targets and proper monitoring and evaluation strategies for measuring progress is important to fight food insecurity. In addition, NNC is unsuccessful because products with long shelf lives are still much more expensive in Nunavut. Retailers state that this is due to stores running out of certain products before next year's sealift can arrive (Nunavut Food Security Coalition, 2016). Moreover, the cost to transport food remains high. For example, the Harris Meats \& Groceries Inc. charges $\$ 1.45$ per kilogram/ $\$ 0.66$ per pound that are subsidized under subsidy level 1 (Harris Meats \& Groceries Inc., 2017). The Nunavut Food Security Coalition found that food transported by the Nutrition North Program is spoiled on route (Nunavut Food Security Coalition, 2016). Therefore, the government has not addressed the issue of transportation and the associated high costs. Lastly, NNC does not ensure that everyone is getting the food that they need to sustain themselves. Other organizations have provided additional funds to help Nunavutans. For example, an Emergency Food Voucher program was opened for people to access food if in an emergency. Often, the Royal Canadian Mountain Police (RCMP), Family Services, and other essential service staff have referred several Elders, individuals and families that require items such as immediate food, diapers, baby formula or iron-rich foods for children diagnosed with tuberculosis (TB) to use this initiative. The average total voucher redemption amount is $\$ 115$. However, the initiative only provides one-off immediate relief (Newman, 2017). Therefore, the additional food voucher suggests that the approach to subsidies is not thoroughly meeting the needs of the Nunavutans. What is even more concerning that government officials are recommending people to use other programs rather than encourage the NNC to solve the issues.

Regarding accountability, according to the auditor general, the program lacks transparency because it is unclear if the residents are saving money (Bambury, 2015). The locals state that the funding is given to stores that have been defrauding the Inuit for many years (Bambury, 2015). The program lacks verifying if full subsidies are being passed to the consumers. "The Department did not require information on profit margins, either in its contribution agreements with retailers or through its compliance reviews of retailers, which is necessary to verify 
that the subsidy is fully passed on to consumers." (Government of Canada, Office of the Auditor General of Canada, 2014). The lack of transparency suggests that the program is contributing to a business bottom line instead of reducing grocery costs (Newman, 2015b). The determination by the auditor general suggests that the program is ineffective because there is more benefit to businesses rather than to Nunavutians. It is important to note that in 2014, after the audit, the Government of Canada increased 11.3 million to the subsidy budget for 2014-2015 and created "a new 5\% annual compound escalator for the food subsidy budget to help it keep pace with the growing demand for perishable nutritious food in the north." (Bambury, 2015; Government of Canada INAC, 2017c). Therefore, the government recognized the need that the program needed more funding to curb food insecurity. Generally, there seems to be limited good performance. The program needs to be changed to substantially increase results for the program to be more effective.

Lastly, regarding voice and legitimacy, in 2011, when the program was introduced, the government held a public consultation meeting to discuss access to food and goods (Kativik Regional Government, 2011). In 2016, the government sought input from community members and other stakeholders like the local governments and northern transportation companies on how the program could be more transparent, cost-effective, and culturally appropriate. There were 20 meetings held (Government of Canada - INAC, 2017d). The public consultation is important because it searches for public concerns to improve the efficiency, transparency, and public involvement in the program. In previous discussions, the community members stated that they want the government to implement policies to help lower the cost (Socha et al, 2012, p. 10). At the public meetings, input varied from including flour, rice, barley, beans, and macaroni under the highest subsidy, focusing on specific foods for children and the elderly. Also, they requested to provide subsidies directly to the consumer and not the retailer and that the governments should find an alternative solution (Government of Canada - INAC, 2017e). Therefore, the communities are continuously engaged in refining and improving the program and even encouraging the introduction of new policies or programs. However, no recent suggests have been implemented yet. Ongoing communication, collaboration and implementation will continue to successfully achieve the principle of voice and legitimacy.

Overall, the Government of Canada does a good job following the principles for good governance. Regarding legitimacy and voice, the government had multiple public consultations that allowed for the people in Nunavut to voice their opinions and suggestions. However, the people mentioned that they wanted an alternative solution, which the government has not yet considered. Also, the government should collaborate with the territorial and local government and for-profit/ not-for-profit organizations to improve the program. Since NNC is similar to the old food mail program that was not very successful, it suggests that the government lacks innovativeness and strategic decision thinking. Regarding fairness, NNC is fair when distributing resources based on distance travelled. Regarding direction, the government has a good goal, with clear objectives, and it is willing to continuously fund. Also, it had a budget of 60 million (Council of Canadian Academies, 2014, p.157) and it has expanded to 77 million) (The Canadian Press, 2016). The increased funding for the program enables the government to keep providing the service and potentially invest in improving the program. Regarding performance, NNC provides an increase of perishable foods available and improves access to food (Government of Canada - INAC, 2017f,g). However, Nunavutans still do not have enough food to be secure or sustainable. The subsidies need to change periodically based on demand for products (Council of Canadian Academies, 2014, p. 157). Also, the subsidy does not change the cost of food (Thompson, 2016, p. 359). INAC could consider purchasing and transporting the foods itself, which will ensure that food is being purchased fairly and the quality is maintained. Alternatively, there could be a partnership with a non-governmental organization to assist in acquiring and distributing food. Lastly, regarding accountability, the governor general stated that there is a lack of transparency of the ongoing subsidies to the communities rather than being taken by the middleman and the government fails to gather the information necessary to measure effectiveness of the program. The government needs to improve the programs performance and transparency to thoroughly ensure good governance

\section{Competencies}

Like the food mail program, NNC is a short-term safety net program because the government was forced to invest in it due to the accessibility issues, malnutrition, and poverty in Nunavut. Even though the subsidy program has had some success, the problem of food security remains an issue. According to subsidy programs done in Mexico and the Philippines, there is no significant decrease in the prevalence of moderate and severe malnutrition in children in Mexico and only a slight decrease of $8.47 \%$ in the Philippines (Kennedy \& Alderman, 1987, p. 49). Therefore, a subsidy program will not effectively tackle the issue of food insecurity. Canada should have done more research assessing subsidy programs before creating and investing in NNC. Also, Indigenous people have already asked for a long-term solution (Government of Canada- INAC, 2017g). The request shows 
that the Indigenous find the NNC subsidies lack the ability to solve the food issues. Moreover, research suggests that when subsidies are used there are usually more benefits to the supplier than to the people (Council of Canadian Academies, 2014, p. 157). Therefore, the result of the suppliers having more benefit should have been considered prior to the start of the program. In addition, price subsidies are more economically costly than finding a long-term solution (Braun, 1992, p. 25). As seen with the increasing cost of the program, more money is being put into the program, but Nunavut continues to be food insecure. The government needs to develop the competencies of strategic thinking, innovation, and build collaborative relationships to create a program or other solutions to ensure food security.

The first competency that the Government of Canada and the Government of Nunavut should improve is strategic thinking. Strategic thinking is the "ability to come up with effective plans in line with an organization's objectives within a particular economic situation". Strategic thinking helps with "reviewing policy issues, performing long term planning, set goals and determining priorities, and identifying potential risks and opportunities" (BusinessDictionary, 2017). One way to improve the current subsidy program is prioritizing food to address certain health concerns. For example, currently, there are major concerns regarding a rise of Tuberculosis (TB) (Murray, 2017). Aside from newborns being vaccinated against TB, good nutrition is important (Puri, 2017 143). Good nutrition can improve the control of the infection. Conditions of poor living conditions, lack of sunlight and poor diet causes people to be more susceptible to TB (Puri, 2017, 142). One tuberculosis infection factor is nutrition. According to a study conducted in Norway between 1963-1975 covering 1.7 million individuals, it showed a correlation between Body Mass Index (BMI) and an increased risk of developing tuberculosis and TB related death (Shetty, 2010, p. 125). In Norway, in 1925, navy cadets reported high TB infections that were improved by adding margarine, cod-liver oil, whole wheat bread, fresh fruit, vegetables, and milk (Shetty, 2010, p. 125). In Denmark, when diets lacked fish and meat, TB increased by $30 \%$ (Shetty, 2010, p. 125). The studies show that when foods were eliminated, it resulted in high rates of TB being contracted. Similarly, in Nunavut, there are less traditional foods eaten and more people have TB. If the government considers higher subsidies and increased TB preventing food's accessibility and availability, then TB may be reduced. Similarly, other current health concerns could be reduced.

Another important competency is innovation because programs need to be continuously transformed to meet growing demands and changing environments. The government needs to branch NNC to include other initiatives which assist in ensuring food is more sustainable and potentially eventually phasing out subsidies. Innovation and strategic thinking intertwine. When developing a program or initiative, the Government of Canada and the Government of Nunavut should consider lands that have a similar food situation to Nunavut. For example, the program could include expanding greenhouses and agriculture. In Inuvik, Northwest Territories, a hockey arena was converted into a greenhouse (Nobel, 2013). Also, Nunavut has the same amount of sunlight as in Yellowknife where carrots and other vegetables are grown (Varga, 2013). It is important to note that there are some successful greenhouses in Nunavut. For example, in Iqaluit, Nunavut, the Iqaluit Community Greenhouse Society (a not-for-profit organization) operates a small community greenhouse on Southern Baffin Island. The greenhouse was built there because the area is part of the Canadian Shield the soils lack nutrients and depth, have low temperatures, and are often too saturated for successful plant growth. (The Iqaluit Community Greenhouse Society, 2014). The greenhouse grows greens (leaf lettuce, spinach, kale, Swiss chard), beans, peas, radish, bok choy, carrots, various herbs, tomatoes, and strawberries (Nobel, 2013; The Iqaluit Community Greenhouse Society, 2015). However, the greenhouse only operates from June to the end of September depending on the overnight temperatures and use only the passive solar heat from the sun (The Iqaluit Community Greenhouse Society, 2014). It is important to note that soil for greenhouses must be shipped from southern Canada, and maintenance is costly. An additional issue is tradition. Other than seaweed, berries and certain herbs, greens have never been part of the Inuit diet. Therefore, even if grown, the Inuit may not purchase the food. However, change is occurring because Inuit are willing to learn how to grow food (Nobel, 2013). The greenhouse brings the community together and has established important values to follow. The values include: fairness, all workers share the responsibilities of the workload and take equal share of the harvest; education, the community discovers knowledge on growing in the north; charity, a share of the produce goes to a local organization like the Iqaluit Food Centre to help those who need food; and community, it brings the community together (The Iqaluit Community Greenhouse Society, 2015). The values intertwine with the principles of good governance. Another greenhouse, in Naujaat, created a dome shaped greenhouse in 2016 (Skura, 2016). The organization designed "a greenhouse, vertical hydroponic systems, and hybrid raised dirt beds to withstand the cold climate". "The greenhouse has a polycarbonate exterior, solar powered air system, and thermal mass storage that is able to maintain temperatures 30 degrees warmer, relative to the outside climate, entirely from sunlight" (Grow Far North, 2017b). The greenhouse is solar powered for 8 months of the year. With one to three hours of 
sunlight, the greenhouse can heat itself 30 degrees warmer than outside. The greenhouse grows tomatoes, kale, peas, and beans. When the greenhouse is in full production, the vegetable baskets are sold below the cost of purchasing vegetables shipped from southern Canada. Also, the organization, Growing North, is looking for the Government of Nunavut's support in sustaining the greenhouse (Skura, 2016). Growing North's mission is "to sustainably provide fresh, locally grown produce to families living in Northern Canada, at a fraction of the current price, while positively contributing to the educational infrastructure and job market" (Grow Far North, 2017a). As an organization, Growing North values community outreach, sustainable food production, and sustainable operations. (Grow Far North, 2017c). Growing North values overlap with the values of INAC and the Government of Nunavut. Altogether, the greenhouses are beneficial because they provide accessible food all-year round, promote good health, provide an opportunity for employment, and provide an opportunity for educational expansion. The NNC should divert funds to start expanding food delivery and storage strategies since greenhouses can be an effective way to approaching food insecurity.

Aside from looking at initiatives internally, in Canada the Government of Canada and the Government of Nunavut should investigate how other Arctic countries are handling food security and work collaboratively to find solutions. A country with similar circumstances is Greenland. Greenland is an autonomous constituent country within the Kingdom of Denmark. Similarly to Nunavut, it is in the Arctic and a land that is separated from any modernized country with access to convenient transportation routes. Greenland is covered $80 \%$ by ice sheet but in the summer the temperature is approximately $15^{\circ} \mathrm{C}$ and sunlight lasts for 24 hours. Historically, the Vikings had sheep and grew potatoes and the Inuit have continued the practice (Nobel, 2013). Likewise, in Norway, livestock is the major agricultural product, and, although the country is more than self-sufficient in animal products, it remains dependent on imports for cereal crops (Joys et al., 2017). Greenland's Arctic conditions are similar to that of Nunavut in terms of poor soil, changing climate, and high supply costs. Currently, according to the Greenlandic Agriculture Advisory Service for Southwestern Greenland, farms are experimenting growing lettuce, cabbage, and potatoes (Nobel, 2013). On one farm there are 12 different kinds of vegetables. The farm has faced some dry summers but has adapted by building water collection and irrigation systems. The farmer, Sten Pedersen, uses fish carcasses and seaweed as fertilizer. In the middle of his farm there is a small structure that contains turnips, kale, cabbage, cauliflower, three kinds of potatoes, three kinds of onions, spinach, parsley, thyme, rhubarb, celery, beets, carrots, and strawberries. Greens are sold to a local restaurant in Nuuk (Nobel, 2013). The Greenland example shows that it is possible to grow food in the same climate and landscape as in Nunavut. Overall, issues with greenhouses include high operating costs, training in horticulture, culturally inappropriate diets and the energy impact on the environment. In addition, having conversations with Greenland or potentially other arctic states could build a collaborative relationship to address the food insecurity issue in the Arctic. Nunavut and Greenland previously aligned to revise the EU seal ban (Government of Nunavut, 2015). Therefore, they have had a working relationship before and should continue the relationship to address the agricultural deficiency. It is also a way to share ideas and see what has been effective in other states and what are the challenges. If all states with the same conditions have the same challenges, working together the challenges may be solved quicker. In addition, as mentioned previously, Nunavut does not have a ministry of Agriculture. Creating a separate ministry could create more emphasis on the value of food security and focus on specifically designed programs and initiatives. Between 2009-2013 the Government of Canada and Nunavut's Ministry of Economic Development \& Transportation introduced the Growing Forward framework to support sustainable and innovative commercial harvesting activities in Nunavut. The joint federal-territorial investments included sustainability of caribou and musk ox, traditional and commercial community harvest, projects, and a community greenhouse development program (Government of Nunavut, 2009). Unfortunately, there are no results indicated regarding the initiatives because the government does not keep track of funding spent towards different programs (Agriculture and Agri-Food Canada, 2017). The lack of results suggests a lack of transparency and accountability. Similarly, currently, Growing Forward 2 (2013-2018) is in progress. The Government of Canada states that from a federal perspective "Agriculture and Agri-Food Canada administers three broad federal programs (AgriInnovation, AgriCompetitiveness, and AgriMarketing) with \$1 billion under GF2 aimed at generating market-based economic growth in the agricultural sector." It also notes that "the investment under GF2 includes $\$ 2$ billion (an increase of 50\% from Growing Forward) for cost-shared programs on a 60:40 basis delivered by provinces and territories, to ensure programs are tailored to meet regional needs". However, according to their website, there are no initiatives in Nunavut (Agriculture and Agri-Food Canada; Government of Canada, 2017). As a territory that needs the most agriculture experience, it is an issue that there has been no activity or funding for Nunavut. Agriculture can bring values like self-sufficiency, prosperity, and experience to Nunavut which is what the governments value. By more financial investment the sector can be expanded and gain more knowledge on effective and efficient agriculture that will ultimately address food security. 
In addition, another innovative and strategic initiative would be expanding aquaculture. Since fish are part of Inuit traditional diets, farm-fishing all-year will maintain the diets and reduce the amount of fish imported. Fish are a good source of nutritious food because they provide a high source of micronutrients and vitamins (OECD, 2010, p. 346). Aquaculture offers a means to increase production, thereby providing food for a community rather than just one family attempting to fish and feed their family (OECD, 2010, p. 346). Currently, fisheries and aquaculture are limited. Nunavut has commercial turbot, shrimp, and char fisheries (Department of Executive and Intergovernmental Affairs, 2017). Baffin Fisheries is a for-profit corporation that has offshore fisheries and is in the process of developing new inshore fisheries and emerging fisheries (Baffin Fisheries, 2017a). The Government of Canada should consider investing in organizations which want to grow the industry. Aquaculture is contentious because it may have a negative environmental impact (Young, \& Matthews, 2014, p. 17). Many current facilities operate by pumping extra fertilizer, antibiotics, and growth hormones into existing bodies of water, or by keeping fish in pens in oceans or lakes, where the waste products can cause harmful outcomes such as disease outbreaks or algal blooms (Work, 2016) and the maintenance of the mechanics like pumps, storage materials and overall operations, are damaging to the environment (OECD, 2010, p. 354). To address the environmental concerns, aquaculture will need to use a land-based closed-containment recirculating aquaculture system (Tucker \& Hargreaves, 2008, p. 389-395). The system increases the number of farmed fish sustainably because the recirculating aquaculture system cuts the pollution and disease. Also, it reduces "water footprint", which allows for opportunities in areas with limited water resources (Tucker \& Hargreaves, 2008, p. 389-395). Lastly, there are already some collaborative relationships, for example, the National Aquaculture Strategic Action Plan Initiative is engaged with the First Nations to consider their opinions and impact on communities (OECD, 2010, p. 325). To increase collaboration the Government of Canada should invest more in fishing initiatives. From the territorial government, the Ministry of the Environment (MOE) in Nunavut has the Commercial Fisheries Freight Subsidy. The subsidy helps commercial fishers and harvesters cover 50\% of freight costs to assist in competing in markets outside of Nunavut (Nunavut Department of Environment, 2017). Also, the MOE has the Fisheries Development and Diversification Program which funds projects that support research and development initiatives to "strengthen, develop, and diversify" Nunavut's fishing industry (Nunavut Department of Environment, 2017). Lastly, the MOE has the Nunavut Fisheries Training Consortium is a training initiative that assists the Inuit of Nunavut obtain maximum employment and economic benefits from the development of a Nunavut based fishing industry including develop inshore fisheries (Nunavut Department of Environment, 2017). The programs show that Nunavut is involved in fishing and expanding the sector. The Government of Canada should invest in organizations like Baffin Fisheries which good visions and values. Baffin Fisheries vision is "to be the leading producer of premium, wild, cold water seafood." Baffin Fisheries values having an organization that is sustainable and environmentally conscious (Baffin Fisheries, 2017b). As a leader of the industry it ensured good development which is what the Government of Nunavut values and being sustainable aids in the sustainability of food security. Also, creating opportunities for the Inuit to gain education and economic opportunities enforces INAC's value of the Indigenous being self-sufficient and prosperous. Lastly, aquaculture would be an economic advancement. Baffin Fisheries employs many people in the Baffin region and for turbot it can harvest 9,500 metric tonnes which is valued at $\$ 70$ million (Department of Executive and Intergovernmental Affairs, 2017). In 2015 in Quebec, trout aquaculture produced \$7,957,000 and in Ontario it produced \$23,200,000 (Government of Canada, Fisheries and Oceans Statistical Services, 2017). Therefore, aquaculture has an economic benefit. The Government of Canada and the Government of Nunavut purchased a research vessel to allow scientists to collect information on marine species, habitat, and populations in waters adjacent to Nunavut (Department of Executive and Intergovernmental Affairs, 2017). The Government of Canada can expand funding for research and exploration of fishing stalk to determine possible fish available, their sustainability, and their health benefits. Overall, aquaculture is culturally appropriate and can provide many of the essential vitamins and minerals that could improve health and curb food insecurity as well as provide educational and employment opportunities.

\section{Conclusions}

In conclusion, food security is an interdisciplinary concept with many political, social, and economic considerations. Achieving food security and reducing chronic malnutrition requires additional multi-sectoral policies and programs. INAC and Nunavut's government both value progressing the North to be self-sufficient and working towards common goals. Nunavut should specifically have a department to address food to enhance and advance efforts towards food security. Clearly, there are many challenges like transportation, food cost, and climate along with health concerns. The current NNC program aids Nunavut's food insecurity issue by subsidizing food fairly to communities based on need. It also has a decent performance, and allows for northern voices to be heard but it lacks in transparency, but it does not solve the problem of food security. Good 
governance needs to recognize the failures and reform to make improvements. Canada and Nunavut need to improve their innovativeness, strategic thinking, and building collaborative relationships by expanding agriculture and aquaculture in Nunavut. Strategic thinking will not only improve food security but assist in tackling other problems like TB. At the same time, being innovative and building collaborative relationships will bring new ideas and speed up the progress in finding ways to solve not only a Canadian problem but one that affects other countries in the world. The NNC program is a temporary band-aid solution, the more the population increases the more funding the program will need. NNC and the governments are not solving the larger food problem and in fact, may be making it worse by letting time pass and not starting the research and development in Nunavut to make it habitable. Overall, food is essential for all human beings. Good leadership and good governance is an essential part of ensuring food security and sustainability. Without strong foundations of policies, programs, and good governance that meet people's needs, food insecurity will continue to be an issue.

\section{References}

Agriculture and Agri-Food Canada; Government of Canada. (2017, June 05). Growing Forward 2. Retrieved December 14, 2017, from http://www.agr.gc.ca/eng/about-us/key-departmental-initiatives/growing-forward-2/?id=1294780620963

Albala, K. (2011). Food cultures of the world encyclopedia(Vol. 2). Santa Barbara (Calif.): Greenwood. https://doi.org/10.5040/9781474208642

Baffin Fisheries (2017a). Operations \& Products. Retrieved December 14, 2017, from http://www.baffinfisheries.ca/operations-and-products/

Baffin Fisheries (2017b). Vision and Values. Retrieved December 14, 2017, from http://www.baffinfisheries.ca/operations-and-products/mandate/

Bambury, B. (2015, August 28). Nunavut's food crisis is becoming an election issue. Retrieved December 13, 2017, from http://www.cbc.ca/radio/day6/episode-248-an-ex-marine-remembers-katrina-censoring-china-s-market-cras h-nunavut-s-food-crisis-more-1.3204850/nunavut-s-food-crisis-is-becoming-an-election-issue-1.3204965

Braun, J. V. (1992). Improving food security of the poor: concept, policy, and programs. Washington, D.C.: International Food Policy Research Institute.

BusinessDictionary (2017). What is strategic thinking? definition and meaning. Retrieved December 14, 2017, from http://www.businessdictionary.com/definition/strategic-thinking.html

Canadian Organic Growers (2016, August 15). Organic Price Tracker. Retrieved December 14, 2017, from http://www.organicpricetracker.ca/index.php/getprice/all-ontario/cabbage-green

CBC News (2014a, December 04). Are people in Nunavut scavenging for food at landfills? Retrieved December 14,2017 , from http://www.cbc.ca/news/canada/north/rankin-inlet-dump-scavenging-controversy-continues-1.2859162

CBC News (2014b, April 07). Income support in Nunavut: 'It's a very stressful life'. Retrieved December 14, 2017, from http://www.cbc.ca/news/canada/north/income-support-in-nunavut-it-s-a-very-stressful-life-1.2600787

CBC News (2015, July 15). Nunavut food prices: pricey, but how much more pricey? Retrieved December 14, 2017, from http://www.cbc.ca/news/canada/north/food-in-nunavut-costs-twice-as-much-as-canadian-average-1.3152896

Chung, K. (1997). Identifying the food insecure: the application of mixed-method approaches in India. Washington, D.C: International Food Policy Research Institute.

Council of Canadian Academies (2014). Aboriginal food security in Northern Canada: an assessment of the state of knowledge. Ottawa, ON: Council of Canadian Academies.

Dam, K. V. (2008). A place called Nunavut: multiple identities for a new region. Groningen: Barkhuis.

Department of Executive and Intergovernmental Affairs (2017, December 11). Nunavut Economy. Retrieved December 14, 2017, from https://www.gov.nu.ca/eia/documents/nunavut-economy

Edwards, T. (2015, January 1). Nunavut's Food Problem. Retrieved December 14, 2017, from https://uphere.ca/articles/nunavuts-food-problem

Feeding Nunavut (2014). Home. Retrieved December 13, 2017, from http://www.feedingnunavut.com/ 
Ford, J. D., \& Beaumier, M. (2011, March). Feeding the family during times of stress: experience and determinants of food insecurity in an Inuit community. The Geographical Journal, 177(1), 44-61.

Government of Canada - Fisheries and Oceans Statistical Services (2017, January 24). Aquaculture. Retrieved December 14, 2017, from http://www.dfo-mpo.gc.ca/stats/aqua/aqua15-eng.htm

Government of Canada - Indigenous and Northern Affairs Canada (2017a, February 03). Values and ethics code. Retrieved December 13, 2017, from https://www.aadnc-aandc.gc.ca/eng/1448561202027/1448561236166

Government of Canada - Indigenous and Northern Affairs Canada (2017b, May 11). Eligible Food. Retrieved December 14, 2017, from http://www.nutritionnorthcanada.gc.ca/eng/1415548276694/1415548329309

Government of Canada - Indigenous and Northern Affairs Canada (2017c, May 11). How Nutrition North Canada works. Retrieved December 14, 2017, from http://www.nutritionnorthcanada.gc.ca/eng/1415538638170/1415538670874\#tpc1

Government of Canada - Indigenous and Northern Affairs Canada (2017d, May 12). Nutrition North Canada Engagement 2016. Retrieved December 14, 2017, from http://www.nutritionnorthcanada.gc.ca/eng/1464190223830/1464190397132

Government of Canada - Indigenous and Northern Affairs Canada (2017e, May 11). What we heard about Nutrition North Canada. Retrieved December 14, 2017, from http://www.nutritionnorthcanada.gc.ca/eng/1465233643322/1465234133331\#chp2_1

Government of Canada - Indigenous and Northern Affairs Canada (2017f). "Results." Retrieved December 14, 2017, from http://www.nutritionnorthcanada.gc.ca/eng/1415649594068/1415649613120

Government of Canada - Indigenous and Northern Affairs Canada (2017g, August 07). Nutrition North Canada Engagement 2016: Final report of what we heard. Retrieved December 14, 2017, from http://www.nutritionnorthcanada.gc.ca/eng/1491505202346/1491505247821\#chp3

Government of Canada - Office of the Auditor General of Canada (2014). Chapter 6-Nutrition North Canada-Aboriginal Affairs and Northern Development Canada. Retrieved December 14, 2017, from http://www.oag-bvg.gc.ca/internet/English/parl_oag_201411_06_e_39964.html\#hd5f

Government of Nunavut (2009, April 2). Government of Canada and Nunavut launch flexible and innovative growing forward programs for harvesters. Retrieved December 14, 2017, from http://www.news.gov.nu.ca/2009/april/april2.pdf

Government of Nunavut (2015, April 24). Government of Nunavut and Greenland release joint statement. Retrieved December 14, 2017, from https://www.gov.nu.ca/eia/news/government-nunavut-and-greenland-release-joint-statement

Government of Nunavut (2017a). Government of Nunavut. Retrieved December 13, 2017, from https://www.gov.nu.ca/

Government of Nunavut (2017b). Inuit Societal Values. Retrieved December 13, 2017, from https://www.gov.nu.ca/information/inuit-societal-values

Government of Nunavut (2017c). Mission \& Vision. Retrieved December 13, 2017, from https://www.gov.nu.ca/edt/vision-and-mandate-1

Government of Nunavut (2017d). Nunavut Quick Facts. Retrieved December 14, 2017, from http://stats.gov.nu.ca/en/home.aspx

Graham, J., Amos, B., \& Plumptre, T. (2015, August). Principles for Good Governance in the 21st Century. Retrieved December 13, 2017, from Institute of Governance http://unpan1.un.org/intradoc/groups/public/documents/UNPAN/UNPAN011842.pdf.

Grow Far North (2017a). Home. Retrieved December 14, 2017, from http://www.growfarnorth.com/

Grow Far North (2017b). How it Works. Retrieved December 14, 2017, from http://www.growfarnorth.com/how-it-works1

Grow Far North (2017c). About Us. Retrieved December 14, 2017, from http://www.growfarnorth.com/about-header/

Health Canada (2012, July 25). Household Food Insecurity In Select Provinces and the Territories in 2009-2010. Retrieved December 13, 2017, from https://www.canada.ca/en/health-canada/services/food-nutrition/food-nutrition-surveillance/health-nutrition 
-surveys/canadian-community-health-survey-cchs/household-food-insecurity-canada-overview/household-f ood-insecurity-select-provinces-territories-2009-2010.html

Harris Meats \& Groceries Inc. (2017). Shipping Rates. Retrieved December 14, 2017, from http://www.harrismeatsandgroceries.com/Nunavut-Shipping-Prices.html

Health Canada. (2012, July 27). Nutrition North Canada. Retrieved December 14, 2017, from https://www.canada.ca/en/health-canada/services/food-nutrition/healthy-eating/nutrition-north-canada.html

Joys, C., Christensen, J., Sandvik, G., \& Enander, H. (2017, September 19). Norway. Retrieved December 14, 2017, from https://www.britannica.com/place/Norway/Agriculture-forestry-and-fishing

Kativik Regional Government. (2011, October 24). Nutrition North Canada Public Consultation. Retrieved December 14, 2017, from http://www.krg.ca/images/stories/docs/Communiques_en/11_08_NNC_hearings_information_final_eng.pdf

Kennedy, T., \& H. Alderman (1987). Comparative analyses of nutritional effectiveness of food subsidies and other food-related interventions. Washington, D.C..: International Food Policy Research Institute.

Kirschenbaum, H. (2013). Values clarification in counseling and psychotherapy: practical strategies for individual and group settings. New York: Oxford University Press. https://doi.org/10.1093/acprof:oso/9780199972180.001.0001

McDonald, B. (2013). Food power: the rise and fall of the postwar American food system. New York: Oxford University Press.

Moran, E. F. (2015). Human adaptability: an introduction to ecological anthropology (3rd ed.). Boulder, CO: Westview Press.

Murray, N. (2017, October 08). 'Her story has resonated': Nunavut teen's death drives Inuit, federal task force on TB in the North. Retrieved December 14, 2017, from http://www.cbc.ca/news/canada/north/inuit-tuberculosis-task-force-1.4345734

Newman, T. (2015a, August 18). Nunavut; a Hunter-Gatherer Society Adapting to Change. Retrieved December 14, 2017, from http://www.feedingnunavut.com/nunavut-a-hunter-gatherer-society-adapting/

Newman, T. (2015b, March 7). Feeding My Family. Retrieved December 14, 2017, from http://www.feedingnunavut.com/feeding-my-family/

Newman, T. (2017, January 25). Emergency Food Vouchers - serving people that need immediate assistance. Retrieved December 14, 2017, from http://www.feedingnunavut.com/emergency-food-vouchers-serving-people-that-need-immediate-food-assistance/

Nobel, J. (2013, October 18). Farming in the Arctic: It Can Be Done. Retrieved December 14, 2017, from https://modernfarmer.com/2013/10/arctic-farming/

Nunavut Bureau of Statistics (2015, March 18). Canada's Population Estimates. Retrieved December 13, 2017, from http://www.stats.gov.nu.ca/Publications/Popest/Population/Nunavut\%20and\%20Canada\%20\%20Population \%20Estimates\%20StatsUpdate,\%20Fourth\%20Quarter\%202014.pdf

Nunavut Bureau of Statistics (2017, January 9). Health. Retrieved December 14, 2017, from http://www.stats.gov.nu.ca/en/Social\%20health.aspx

Nunavut Department of Environment (2017, November 07). Fisheries and Sealing Programs. Retrieved December 14, 2017, from https://gov.nu.ca/environment/information/fisheries-and-sealing-programs

Nunavut Bureau of Statistics (2016, July 1). Population Estimates. Retrieved December 14, 2017, from http://stats.gov.nu.ca/en/Population\%20estimate.aspx

Nunavut Food Security Coalition (2016, September). Nunavut Food Security Coalition 2016 Meeting Report. Retrieved December 14, 2017, from http://www.gov.nu.ca/sites/default/files/2017-01-26_-_2016_nfsc_meeting_report_english_0.pdf

Nunavut Tourism (2017). Weather \& Climate. Retrieved December 14, 2017, from http://nunavuttourism.com/about-nunavut/weather-climate

OECD. (2010). Advancing the aquaculture agenda: workshop proceedings. France: OECD Publications.

Patria, B. (2011). Problem-Based Learning, Graduates' Competencies and Career Success. Yogyakarta, 
Indonesia: Inparametric Press.

Puri, A. S. (2017). How to Prevent Common Diseases: A Comprehensive Guide to Detect, Prevent and Combat Common Fatal Diseases. New Dehli, India: Sterling Pvt. Ltd.

Rea, K. J. (2017, July 05). Nunavut. Retrieved December 14, 2017, from https://www.britannica.com/place/Nunavut

Shetty, P. S. (2010). Nutrition, immunity, and infection. Wallingford (UK): CABI. https://doi.org/10.1079/9780851995311.0000

Skura, E. (2016, June 14). 'We are ready to grow:' New greenhouse could be game changer in Naujaat, Nunavut. Retrieved December 14, 2017, from http://www.cbc.ca/news/canada/north/naujaat-nunavut-growing-north-project-1.3633295

Socha, T., Zahaf, M., Chambers, L., Abraham, R., \& Fiddler, T. (2012). Food Security in a Northern First Nations Community: An Exploratory Study on Food Availability and Accessibility. Journal of Aboriginal Health, 8(2), 5-14. Retrieved December 14, 2017, from http://www.naho.ca/jah/english/jah08_02/08_02_food-security.pdf

Statistics Canada (2017, March 31). Average weekly earnings (including overtime), by province and territory. Retrieved December 14, 2017, from http://www.statcan.gc.ca/tables-tableaux/sum-som/101/cst01/labr79-eng.htm

Stern, P. R. (2010). Daily life of the Inuit. Santa Barbara, CA: Greenwood.

Stevenson, V. (2017, March 25). Iqaluit grocery shelves left bare as ice and fog hinder food shipments. Retrieved December 13, 2017, from

https://beta.theglobeandmail.com/news/national/iqaluit-grocery-shelves-left-bare-as-ice-and-fog-hinder-foo d-shipments/article25543820/?ref=http\%3A\%2F\%2Fwww.theglobeandmail.com\&

Strapagiel, L. (2012, June 11). Nunavut Food Prices: Poverty, High Costs Of Northern Businesses Leave Some Inuit Unable To Cope With Expenses. Retrieved December 14, 2017, from http://www.huffingtonpost.ca/2012/06/11/nunavut-food-prices-protest-inuit-poverty_n_1588144.html

Strong, W. (2017, October 28). Nunavut voters head to the polls with education, language, Inuit participation in government top of mind. Retrieved December 14, 2017, from http://www.cbc.ca/news/canada/north/nunavut-for-inuit-1.4376284

The Canadian Press (2016, December 05). Food in North often expired - even at high prices and with subsidy, good food is hard to find. Retrieved December 14, 2017, from

http://nationalpost.com/news/canada/federal-subsidy-failing-to-keep-northern-food-healthy-affordable-stud $\mathrm{y} / \mathrm{wcm} / \mathrm{a} 2 \mathrm{e} 03 \mathrm{dc} 8-0 \mathrm{~d} 84-4418-8761-\mathrm{bfcb} 567077 \mathrm{c} 7$

The Canadian Press (2014, November 25). Highlights of the Auditor General's 2014 fall report. Retrieved December 14, 2017, from http://www.macleans.ca/news/canada/highlights-of-the-auditor-generals-2014-fall-report/

The Iqaluit Community Greenhouse Society (2014, June 16). About the Society. Retrieved December 14, 2017, from https://iqaluitgreenhouse.com/about/

The Iqaluit Community Greenhouse Society (2015, November 09). FAQs. Retrieved December 14, 2017, from https://iqaluitgreenhouse.com/faqs/\#5

Torero, M. (2014, October 15). Food security brings economic growth — not the other way around. Retrieved December 13, 2017, from

http://www.ifpri.org/blog/food-security-brings-economic-growth-not-other-way-around

Thompson, V. D. (2016). Health and health care delivery in Canada. Toronto, ON: Elsevier Canada

Tucker, C. S., \& Hargreaves, J. A. (2008). Environmental best management practices for aquaculture. Ames, IA: Blackwell. https://doi.org/10.1002/9780813818672

University of Toronto (2017, June 15). Food Insecurity Policy Research - Household food insecurity is a serious public health problem that affects over 4 million Canadians. Retrieved December 13, 2017, from http://proof.utoronto.ca/

Varga, P. (2013, June 25). Arctic farmer ponders Nunavut's growth potential. Retrieved December 14, 2017, from 
http://www.nunatsiaqonline.ca/stories/article/65674arctic_farmer_ponders_nunavuts_growth_potential/

Work, K. (2016, December 2). New Sustainable Aquaculture Methods Promise Healthier Fish and Lakes - Food Tank. Food Tank. 2013-2016 Food Tank. Retrieved December 14, 2017, from https://foodtank.com/news/2013/03/new-sustainable-aquaculture-methods-promise-healthier-fish-and-lakes/

World Food Programme (2017). Climate Impacts on Food Security. Retrieved December 14, 2017, from https://www.wfp.org/climate-change/climate-impacts

Young, N., \& Matthews, R. (2014). The Aquaculture Controversy in Canada: Activism, Policy, and Contested Science. Vancouver: UBC Press.

\section{Appendix}

The following is an email correspondence from Agriculture and Agri-Food Canada.

Cited as: (Agriculture and Agri-Food Canada, 2017)

Karolina Stecyk

Tue 11/21, 11:01 AM INFO (AAFC/AAC) <INFOAAFC-AAC@AGR.GC.CA>

Hi Sophie,

So from my understanding that Agriculture and Agri-Food Canada does not track/record the Agricultural Policy Framework, Growing Forward, Growing Forward 2 initiatives/programs that it funds in Nunavut.

How much of the $\$ 3$ billion investment is estimated to go to Nunavut?

Also, in regard to NNC, there is no plan to find a long-term solution to the food issue, just keep increasing funding.

Thanks.

Best,

Karolina

From: INFO (AAFC/AAC) <INFOAAFC-AAC@AGR.GC.CA>

Sent: Tuesday, November 21, 2017 10:15:20 AM

To: Karolina Stecyk

Subject: RE: Question - K. Stecyk (236465)

Good morning Karolina,

For nearly 15 years, the federal, provincial and territorial (FPT) governments have worked collaboratively to develop and implement three consecutive agricultural policy frameworks (i.e., Agricultural Policy Framework, Growing Forward, Growing Forward 2) to encourage innovation, investment, risk management, and sustainability while supporting the growth and prosperity of Canada's agricultural sector. The current framework, Growing Forward 2, is set to end on March 31, 2018.

In July 2017, FPT Ministers agreed to launch a new agricultural policy framework, the Canadian Agricultural Partnership (CAP), and it will be in place on April 1, 2018. CAP is a five-year, $\$ 3$ billion investment by FPT governments to strengthen the agriculture, agri-food and agri-based products sector.

Annually, results are captured in Agriculture \& Agri-Food Canada's Departmental Performance Report which can be found at

http://www.agr.gc.ca/eng/about-us/planning-and-reporting/departmental-results-reports/?id=1219248798716. 
Additionally, results for Nutrition North Canada (NNC), a subsidy program to provide Northerners in isolated communities with improved access to perishable nutritious food, can be found at http://www.nutritionnorthcanada.gc.ca/eng/1415649594068/1415649613120.

In response to your specific questions on the Government of Nunavut's Growing Forward 2 program activities, it is recommended that you either consult their website (www.gov.nu.ca) or call them directly at 1-877-212-6438.

Hoping that this information will be helpful to you.

\section{Sophie Poirier-Geve}

Communications Officer | Agente de communications

Public Information Request Services | Service des renseignements au public

Agriculture and Agri-Food Canada | Agriculture et Agroalimentaire Canada

T7-10-147, 1341 Baseline Rd.| T7-10-147, 1341, Ch. Baseline

Ottawa, ON | Ottawa (ON) K1A 0C5

E-mail: info@agr.gc.ca|Courriel : info@agr.gc.ca

Telephone | Téléphone 613 773-1000

Facsimile | Télécopieur 613 773-1081

Teletypewriter | Téléimprimeur 613 773-2600

Government of Canada | Gouvernement du Canada

\section{Copyrights}

Copyright for this article is retained by the author(s), with first publication rights granted to the journal.

This is an open-access article distributed under the terms and conditions of the Creative Commons Attribution license (http://creativecommons.org/licenses/by/4.0/). 